\title{
EM BUSCA DOS RASTROS DE UM CORPO INSEPULTO: REFLEXÕES SOBRE PALAVRAS CRUZADAS, DE GUIOMAR DE GRAMMONT
}

\author{
TRACING AN UNBURIED BODY: \\ REFLECTIONS ON PALAVRAS CRUZADAS, BY GUIOMAR DE GRAMMONT
}

DOI 10.20873/uft2179-3948.2021v12n2p118-140

Gínia Maria Gomes ${ }^{1}$

Por eso, los sujetos concernidos, hijos, esposos, madres, hijas, parejas, compañeras, padres, dicen tras el tsunami que viven en el vacio, que su ausente es un presente, que ni vive ni muere, que es pero que no.

Gabriel Gatti

Resumo: O propósito deste artigo é realizar um estudo sobre Palavras Cruzadas (2015), de Guiomar de Grammont. A leitura terá por foco a protagonista do romance, marcada pelo desaparecimento do irmão, pois sem o corpo a cerimônia fúnebre não aconteceu. O luto em suspenso traz, como principal implicação dessa ausência, sua presença constante. Em busca dos rastros dele, ela faz uma viagem. Nela, em vez de descobrir seu paradeiro, a realidade cruel da guerrilha impõe-se: naquela selva, os guerrilheiros foram executados. E seus corpos permaneceram desaparecidos, pois o governo ditatorial tentou apagar esse capítulo da história do país.

Palavras-chave: Ditadura; guerrilha do Araguaia; desaparecimento; trauma; apagamento.

Abstract: This article aims at studying the novel Palavras Cruzadas (2015), by Guiomar de Grammont. It focuses on the main character, deeply affected by her brother's disappearance and the impossibility of a funeral since his body has never been found. The unresolved grief has, as a major implication of this absence, her brother's constant presence. As a way to trace back his steps, she goes on a trip. On it, she is unable to discover his whereabouts, but the cruel reality of Araguaia Guerrilla unveils: on the jungle, guerrillas have been murdered. And their bodies remain vanished, for the dictatorial government has tried to erase this chapter of the country's history.

\footnotetext{
${ }^{1}$ Professora titular de Literatura Brasileira do Instituto de Letras da Universidade Federal do Rio Grande do Sul (UFRGS). E-mail: giniagomes@gmail.com ORCID: https://orcid.org/0000-0002-6161-6357
} 
Keywords: Dictatorship; Araguaia Guerrilla; disappearance; trauma; erasing

\section{Introdução}

Um número expressivo de romances brasileiros contemporâneos, publicados sobretudo a partir de 2014, tem resgatado o período da ditadura civil-militar no Brasil. A revisitação a esses anos de chumbo, em que os direitos humanos foram desrespeitados, não permite esquecer os crimes hediondos que, então, se tornaram a regra. Esses crimes bárbaros, que a Lei de Anistia tentou apagar ao deixar impunes os seus responsáveis, são postos em evidência nessas narrativas. Esse movimento é fundamental para que esse passado não seja esquecido, conforme as reflexões de Ettore Finnazzi-Agrò (2014) e Eurídice Figueiredo (2017).

Finazzi-Agrò (2014, p. 180) considera que apenas a literatura consegue dizer o que escapa às várias narrativas, sejam escritas por agentes repressores, sejam por militantes que fizeram a resistência:

Nesse sentido, a meu ver, é só numa dimensão ficcional, é só no âmbito da literatura que podemos surpreender o nefas habitando nas dobras da História oficial, chegando assim a entrever aquele interdito que sempre se diz na defasagem e/ou na conjuntura entre duas versões contrapostas do mesmo acontecimento.

É assim que, segundo o pesquisador, “[...] apenas a literatura conseguiu dizer aquela verdade que, no âmbito histórico, balançava (e que, de forma macabra, continua balançando) entre a afirmação e a negação, entre a denúncia e a ultrajante incapacidade de admitir o horror extremo dos "campos"” (FINAZZI-AGRÒ, 2014, p. 180). Mais adiante, o crítico afirma que “[...] a literatura cumpre um papel de suplência em relação à historiografia, conseguindo às vezes dizer o abjeto [...], conseguindo nos entregar aquela verdade nefanda e inter-dita que o relato e a crônica dos acontecimentos não podem e, talvez, não devam dizer: [...]” (FINAZZIAGRÒ, 2014, p. 182). Ao representar as agruras de um tempo de exceção, a literatura mostra “[...] através da sua escrita e das imagens por ele [autor] produzidas, uma verdade material 'física', eu diria - da qual nenhuma História poderia dar conta senão traindo ao seu estatuto epistemológico" (FINAZZI-AGRÒ, 2014, p. 188). Isso coloca a literatura em uma posição privilegiada em relação à História, pois ela revela as idiossincrasias de uma época em que vozes dissidentes eram caladas.

Figueiredo (2017) também faz uma reflexão sobre o importante papel da literatura, na representação de cenas traumáticas, impedindo que sejam esquecidas. Nesse sentido, os textos literários têm primazia em relação aos escritos dos historiadores: 
E, no entanto, a despeito do enorme trabalho realizado por historiadores e jornalistas, só a literatura é capaz de recriar o ambiente de terror vivido por personagens afetados diretamente pela arbitrariedade, pela tortura, pela humilhação, pois como afirma Jacques Rancière (2009, p. 58), "o real precisa ser ficcionado para ser pensado". (FIGUEIREDO, 2017, p. 43)

Os estudiosos evidenciam que apenas a literatura, ao ficcionalizar os acontecimentos pregressos, consegue dar visibilidade a um período de extrema violência, em que a exceção se normatizara. Ao fazê-lo, iniciam um processo de elaboração desse passado traumático. Papel esse que é extensivo a todas as manifestações artísticas que tratam do assunto. No caso específico do romance, muitas(os) escritoras(es) seduzidas(os) pelo tema centralizam suas histórias no período. Resgatando-o do apagamento, estão procedendo ao enterro dos mortos insepultos, pois, conforme as palavras de Jeanne Marie Gagnebin (2006, p. 112), “o túmulo é signo dos mortos: túmulo, signo, palavra, escrita, todos lutam contra o esquecimento". Nessas narrativas, é dada visibilidade às histórias interditas pela História oficial. Através das suas personagens, essas criações têm o mérito de reproduzir o clima de horror constitutivo daquela época.

Diversas faces da ditadura são descobertas nos romances contemporâneos. Entre elas, refere-se à tortura, ao desaparecimento forçado, ao sequestro de crianças e ao exílio como as recorrentes. Além disso, convém destacar o episódio da guerrilha do Araguaia, que leva às últimas consequências a desaparição, pois além da morte física, os agentes repressores procuram apagar os rastros do extermínio, tentando submetê-lo ao mais completo silenciamento. Nas palavras de Roberto Vecchi (2014, p. 133), o

Araguaia, hoje, não é só mais uma página em branco da história (ainda largamente
por escrever) da ditadura militar no Brasil (1964-1985). É, um simultâneo, o mais
espectral dos seus silêncios e, por paradoxo, se diria, o mais contemporâneo dos seus
silêncios, das suas narrativas lacunosas e dispersas.

Em outro estudo, o pesquisador novamente ressalta a relevância do tema, atentando para sua atualidade: "O caso do Araguaia torna esse tema de enorme atualidade porque Araguaia é o buraco negro mais vistoso [...]" (VECCHI, 2020, p. 53-54).

Palavras cruzadas, objeto deste ensaio, está entre os romances que têm por tema a Guerrilha do Araguaia. ${ }^{2}$ Nele, uma jovem, Sofia, propõe-se perseguir os rastros do irmão desaparecido. Em sua jornada, várias vozes se cruzam, compondo um mosaico de narrativas sobre o paradeiro do irmão, porém nenhuma delas têm qualquer primazia sobre as demais. Cada uma apresenta-se com lacunas, as quais nunca são preenchidas. Entre as possiblidades dessa

\footnotetext{
${ }^{2}$ Os romances Azul-corvo (2010), de Adriana Lisboa, e Antes do passado: o silêncio que vem do Araguaia (2012), de Liniane Haag Brum, também têm essa guerrilha como tema.
} 
narrativa plural, essa personagem será o foco dessa discussão. Primeiro, pretende-se atentar para seu estado emocional, para seu sentimento de incompletude, decorrente do luto em suspenso. Depois, observar sua trajetória ao propor-se seguir os rastros do irmão desaparecido. ${ }^{3}$

\title{
1 "Aquela falta pulsava, buraco negro no espaço."
}

É da Antígona, de Sófocles, a epígrafe do romance: "Seu irmão jazia insepulto; ela não quis que ele fosse espedaçado pelos cães famintos ou pelas aves carniceiras" (GRAMMONT, 2015, p. 7). No trecho, fica explícito o quão imprescindível é dar uma sepultura ao irmão. Para isso, Antígona se impõe contra Creonte, que proibira tal ato. Vladimir Safatle (2010) faz reflexões sobre esse interdito de não enterrar Polinices. Segundo ele, tal determinação “[...] só pode significar não acolher sua memória através dos rituais fúnebres, anular os traços de sua existência, retirar seu nome" (SAFATLE, 2010, p. 239). Enterrar os mortos é um ritual que está presente em Homero, como lembra Gagnebin (2010, p. 184): "Desde os tempos homéricos se celebra a necessidade humana de enterrar os mortos, de recolher os corpos dos guerreiros mortos, de não deixar nenhum cadáver sem sepultura adequada".

No caso dos desaparecidos, os apagamentos dos rastros e a negativa dos assassinatos são óbice para a cerimônia fúnebre: "Não se pode nem afirmar que as pessoas morreram, já que elas desapareceram sem deixar rastros, sem deixar também a possibilidade de homenagem e de luto por parte dos seus próximos" (GAGNEBIN, 2006, p. 116). A realização dessa cerimônia é fundamental para aqueles que perderam entes queridos, pois dela depende a elaboração do luto. Não efetuar esse rito traz implicações sérias aos familiares impedidos de sepultar os seus: são acometidos por um sofrimento impossível de ser aplacado. O luto em suspenso é responsável pela dor sem remissão que os acabrunha, deixando-lhes a vida paralisada. Esse é o drama que vivem os familiares de desaparecidos políticos. Janaína de Almeida Teles (2010, p. 269, grifos da autora), reporta-se sobre o quanto o desconhecimento acerca do destino de uma pessoa tem consequências funestas para os familiares:

\begin{abstract}
A inexistência de um corpo ou de uma notícia a respeito da morte aumentava o desespero dos familiares, tornando impossível o esquecimento. O silêncio introduzido pelo terror do desaparecimento cria uma situação sem um fim, perpetuando a tortura que é vivenciar a ausência de seus corpos e de informações.
\end{abstract}

\footnotetext{
${ }^{3}$ Os diários - do irmão e, certamente, da cunhada -, que Sofia lê ao longo de seu itinerário, que podem ser considerados as principais vozes do romance, não serão objeto dessa leitura. No ensaio "Memórias de uma 'guerra suja' em Palavras cruzadas, de Guiomar de Grammont” (2020), Sheila Katiane Staudt faz um interessante estudo sobre esses diários.
} 
Sem o corpo, sem saber o que lhe aconteceu, o sofrimento se vivifica diuturnamente. Diante de um desaparecimento, não há, conforme a pesquisadora, uma delimitação entre “[...] o que ocorreu antes e tudo o que aconteceu depois" (TELES, 2010, p. 269). E isso é motivo de um sofrimento redivivo. Ao analisar o conto "O velório", de Bernardo Kucinski, Jaime Ginzburg (2020, p. 119) faz considerações sobre o quão marcante é o desaparecimento de um familiar: "Nesses casos, a dor da perda pode se prolongar indefinidamente".

Essa é a situação de Sofia, a protagonista de Palavras Cruzadas - e de seus pais. Ela é atormentada pelo sumiço do irmão Leonardo, que partiu quando ela era criança. Desde muito cedo, é assombrada pela sua ausência, pelo temor do que pudesse lhe acontecer. Em um episódio ocorrido na escola, um dos colegas se refere a ele como "subversivo" (GRAMMONT, 2015, p. 50). Ora, ela já conhecia o termo através da TV, que lhe conferia uma carga negativa, tanto é assim que a menina "tinha pavor deles" (GRAMMONT, 2015, p. 50). Tendo introjetado o que era veiculado pela mídia, ao ouvir o termo sendo atribuído ao irmão, Sofia sofre um impacto: "E agora falavam que o irmão que ela adorava era um subversivo? Como podia ser?" (GRAMMONT, 2015, p. 50). Safatle (2010, p. 238) esclarece que os governos totalitários procedem à "[...] violência da eliminação simbólica" de seus opositores. "Neste sentido, ele é a violência da imposição do desaparecimento do nome" (SAFATLE, 2010, p. 238). Esse se transforma em um ser “inominável” e "pode, inclusive, receber, não um nome, mas uma espécie de 'designação impronunciável' que visa isolá-lo em um isolamento sem retorno. 'Subversivo', “Terrorista"” (SAFATLE, 2010, p. 238). É o que acontece com Leonardo ao ser denominado subversivo pelas crianças. Sofia não consegue se confrontar com o paradoxo de perceber o irmão amado com essa atribuição negativa. Aos prantos, expõe seu dilema ao pai. As explicações paternas apresentam a questão sob outro ângulo, o que lhe permite transferir para ele "o medo que ela sentia" (GRAMMONT, 2015, p. 50): "passou a partilhar com ele [pai] o temor pela segurança de Leonardo"(GRAMMONT, 2015, p. 50).

O irmão de quem se despede ainda na infância (não é precisada a idade de Sofia, todavia, a reação às palavras do colega e o fato de sentar-se no colo do pai, indicam que é ainda uma criança), transforma-se em uma ausência que se presentifica, fazendo com que sua vida permaneça em suspensão:

Nenhum corpo foi velado, não houve lágrimas, despedidas ou alma encomendada aos céus. Leonardo tornou-se uma presença eterna. Sofia sentia culpa, mesmo sem motivo. Sua vida se suspendeu naquela ausência. Era um sentimento difuso. Em sua consciência, ela sabia que não era responsável pelo desaparecimento dele, mas seu irmão não voltaria tampouco. Essa falta não permitia que ela construísse nada, nem em sua vida afetiva, nem na profissional. Era uma parede, obstáculo incontornável 
dentro dela. Tudo que ela tentava empreender em sua vida parecia sugado pelo abismo. (GRAMMONT, 2015, p. 56)

Não ter realizado a cerimônia fúnebre, não ter dado uma lápide ao irmão, é a circunstância responsável por seus fracassos, tanto no plano afetivo como no profissional. No final do trecho é explícito quão grande foi o malogro de suas iniciativas: "Tudo [...] sugado pelo abismo". Obsedada pelo pensamento no irmão, entende-se os seus insucessos. Gagnebin (2010, p. 185, grifos da autora) discorre sobre o quanto não enterrar os mortos desaparecidos pode afetar a todos, tendo, por isso mesmo, implicações que excedem a tristeza: "Não sabemos como morreram nem onde estão seus restos - e isso nos impede, a nós todos, mesmo que especialmente a seus familiares e amigos, de poder viver melhor no presente". É o que acontece com a protagonista, cujos insucessos podem ser atribuídos a esse luto interdito pela ausência do corpo, impedindo-a, conforme as palavras da pesquisadora, de ter um presente mais bem vivido.

Aspecto recorrente no romance são as referências a sua impossibilidade de deixar de pensar sobre o destino de Leonardo: "Não sabia o que pensar, porém, sobre o que se referia ao desaparecimento do irmão. Era impossível esquecer" (GRAMMONT, 2015, p. 175). Mais adiante, a mesma ideia é reiterada. Então, é evidenciado que mesmo quando seu pensamento não está direcionado a ele, algum gesto logo impunha a rememoração de circunstâncias similares:

Porém ela não conseguia esquecer. [...] Sempre que ela abraçava um homem mais alto, a reminiscência de um gesto semelhante atravessava por um segundo seu inconsciente, mesmo que ela não estivesse pensando em seu irmão, mesmo que ela não pensasse em nada. Aquela falta pulsava, buraco negro no espaço. (GRAMMONT, 2015, p. 205)

O final do excerto é eloquente em relação às implicações dessa ausência: uma ferida aberta, um sofrimento sem trégua. O verbo "pulsar" é enfático sobre a dor inexorável, constantemente atualizada. A metáfora "buraco negro no espaço" é significativa. Ela aponta para um tormento irremissível, do qual a personagem não consegue fugir, que não consegue esquecer. Dom Paulo Evaristo Arns (2011, p. 12), que amparou familiares de desaparecidos, sendo à época uma referência nessa questão, dá a dimensão desse sofrimento:

Não há ninguém na Terra que consiga descrever a dor de quem viu um ente querido desaparecer atrás das grades da cadeia, sem mesmo poder adivinhar o que lhe aconteceu. O "desaparecido" transforma-se numa sombra que ao escurecer-se vai encobrindo a última luminosidade da existência terrena.

Também Sofia vive um sofrimento insubmisso à palavra, que constantemente recrudesce e se atualiza. "Esse passado que insiste em perdurar de maneira não reconciliada no 
presente, que se mantém como dor e tormento, esse passado não passa" (GAGNEBIN, 2010, p. 185). As palavras da pesquisadora são oportunas para compreender-se a extensão do sofrimento da protagonista.

Um desdobramento desse sofrimento transparece na culpa, aspecto presente em trecho anteriormente citado: "Sofia sentia culpa, mesmo sem motivo". Embora tivesse consciência de que não teve nenhuma ingerência em seu desaparecimento, um "sentimento difuso", imune à racionalização, a perturba. Além dessa, há outras referências no romance mostrando a força como ela se impõe, invadindo momentos em que se permite algum prazer ou alegria:

A lembrança do irmão se transformava em uma suave autocensura, a cada vez que ela
ia ao cabeleireiro fazer as unhas ou quando comprava uma roupa ou uma bolsa nova.
Nos momentos felizes, quando se regozijava com a vida, o pensamento voltava, mais
incômodo do que nunca. Sofia não se sentia no direito de ser feliz. (GRAMMONT,
2015, p. 60)

Em outra ocasião, novamente é comentado esse instaurar da culpa, ofuscando instantes em que poderia estar feliz: "Não havia sono que não fosse visitado pela presença de seu irmão, nem momento de felicidade que não viesse empanado por aquela ausência. Uma culpa fina e constante a trespassava, por ter sobrevivido, por estar no mundo e poder aproveitar os momentos felizes" (GRAMMONT, 2015, p. 205). Interessante é o episódio da despedida do irmão, ocorrido na infância, também percebido sob o prisma da culpa. Seu pedido para que não partisse é visto como não suficientemente contundente: "Por toda a vida, porém, essa cena a torturava: achava que não tinha pedido com tanta ênfase, que devia ter sido mais firme, devia ter inventado alguma coisa para impedi-lo de ir, uma doença, o que quer que fosse. Mas nada lhe ocorreu" (GRAMMONT, 2015, p. 205). Figueiredo (2017, p. 94) ressalta o sofrimento dos familiares decorrente da ausência do corpo e alerta sobre o "sentimento de culpa", pela não realização da cerimônia fúnebre: “A espera, misturada à angústia, prolonga o sofrimento e desencadeia o sentimento de culpa. O desaparecido torna-se um fantasma que continua habitando o mundo mental dos vivos".

O trauma do irmão desaparecido não é elaborado, revelando-se na dor não redimida pelo luto que o ritual propiciaria. Uma dor reencenada em cada ato seu sob a forma de culpa, que é insubmissa à racionalização. Uma dor que lhe impede de se realizar, o que é determinante para o malogro de seus projetos. Uma dor que está transparente em seu corpo, a qual se manifesta durante a leitura dos diários: na emoção, de que é tomada, e nas suas reações corporais; indício do quanto é afetada, pois a ferida não está cicatrizada. Em alguns momentos, ela precisa interromper a leitura, tomada pelo choro: "Sofia interrompeu a leitura, as lágrimas a impediam 
de ver o que estava escrito" (GRAMMONT, 2015, p. 26). O mesmo se passa logo adiante: "Sofia soluçou alto, ao ler essa frase" (GRAMMONT, 2015, p. 40).

Também é importante ressaltar algumas circunstâncias em que as marcas do sofrimento da protagonista são manifestas no corpo. É através dele que seu desconsolo é extravasado: "Sofia ficou sufocada. Sentia uma dor, na altura do peito, embora não tivesse nenhum problema de saúde" (GRAMMONT, 2015, p. 34). É significativa a explicação de que essa dor manifesta no corpo não representa problema físico. Na realidade, o corpo tem uma memória. Segundo as reflexões de Aleida Assmann $(2011,265)$, “A memória corporal de feridas e cicatrizes é mais confiável do que a memória mental”. A mesma perspectiva da manifestação física do sofrimento, desencadeada pela leitura, pode-se perceber algumas páginas depois: "Sofia fechou o caderno um instante, a pulsação disparatada. Como era difícil para ela acompanhar aquele relato! Mas uma necessidade imperiosa a impedia de parar." (GRAMMONT, 2015, p. 41); ou ainda: "Sofia parou a leitura, um nó na garganta." (GRAMMONT, 2015, p. 73). Em momento posterior, percebe-se nova reação corporal: "Sofia se perguntava, com o abdome contraído, a respiração suspensa. A dúvida começou a se insinuar em seu espírito e a dor vinha junto, como um bisturi, reabrindo, devagar, uma ferida mal cicatrizada" (GRAMMONT, 2015, p. 112). Aqui, o sofrimento redivivo é manifestado no corpo na imagem do bisturi abrindo feridas préexistentes. Ao mesmo tempo, esse exemplo pode ser visto como uma reflexão sobre seu estado, sobre essa dor que o seu corpo deixa transparente. Essa consciência está mais explícita na percepção de que "o relato lhe propunha a escuta de uma dor que a habitava" (GRAMMONT, 2015, p. 162). As imagens "ferida mal cicatrizada" e "dor que a habitava" dialogam com a definição de trauma, que "em grego, [...] significa ferida” (SELIGMAN-SILVA, 2003, p. 49). "Nesse sentido, pode-se caracterizar o trauma como uma escrita duradoura no corpo, oposta à recordação" (ASSMANN, 2011, p. 265). Ao reportar-se ao trauma, Assmann (2011, p. 278) discorre sobre a impossibilidade de traduzi-lo: "Palavras não podem representar essa ferida memorativa do corpo. Ante o trauma, a linguagem comporta-se de forma ambivalente". A dor de Sofia, motivada pelo evento traumático do desaparecimento do irmão, não foi elaborada, estando transparente no corpo.

Nessa iminência, avassalada pela dor, impõe-se o desejo de conhecer o passado do irmão, de saber o que lhe aconteceu. Esse desejo é expresso em diversas oportunidades. É ele que a mobiliza para a viagem. E, no decorrer da mesma, a premência sobre essa necessidade é muitas vezes reiterada, afigurando-se disso depender o rumo da própria vida. Não se sentindo no "direito de ser feliz", ela é compelida a essa busca, a qual encara como "uma 
responsabilidade que lhe cabia", por isso "sentia-se eternamente pressionada a ocupar-se também daquele passado" (GRAMMONT, 2015, p. 60). Vê-la como uma "responsabilidade" e sentir-se "pressionada" põe em foco o quanto a apreensão da verdade sinaliza para uma urgência interna.

Essa imperiosidade de conhecer a vida pregressa do irmão está presente em algumas ocasiões. É nas conversas com Taco, com Marcos e com os pais de Mariana que essa urgência está evidenciada. Para o político, suas palavras são quase uma súplica: “- O que aconteceu? Por favor, preciso muito saber. Sonho com meu irmão ate hoje. Tenho a impressão de que o tempo parou depois que ele se foi. Não vou resolver nada em minha vida enquanto não souber o que aconteceu com ele" (GRAMMONT, 2015, p. 81). Aqui, é posto em foco a aliança entre essa descoberta e o direcionamento de sua vida. Ela verbaliza que está impedida de movimentar-se, dependente das implicações desse desaparecimento. Ao amigo que lhe afirma que “- [...] devia continuar vivendo apesar disso" (GRAMMONT, 2015, p. 88), ela responde: “- Eu só queria saber o que aconteceu” (GRAMMONT, 2015, p. 88). Em seguida, é o narrador, próximo à Sofia, que evidencia sua ânsia por esclarecer o que lhe sucedeu: "Sofia concordou, consternada, mas não podia pensar em outra coisa. Precisava saber alguma coisa, mínima que fosse, sobre o destino do irmão desaparecido" (GRAMMONT, 2015, p. 89). A mesma necessidade de saber sobre o que se passou com ele é expressa para os pais da cunhada: “- [...] Bem, talvez vocês tenham preferido esquecer esse assunto, mas eu preciso saber sobre o que aconteceu a meu irmão, por isso estou aqui” (GRAMMONT, 2015, p. 220, grifo da autora). Atente-se para o grifo em "preciso", pois esse enfatiza sobre como é primordial se inteirar desse passado.

No entanto, esse acercamento do passado não se apresenta como uma trajetória fácil. Não apenas pelo apagamento a que a guerrilha do Araguaia foi submetida (objeto de discussão no próximo item), mas pelo seu próprio temor de desvendar a verdade. Seu anseio por notícias sobre o que lhe sucedeu é permeado pelo receio do que possa encontrar. Esse sentimento antagônico é verbalizado em algumas oportunidades. Em conversa com o reverendo Wright, ao ser advertida sobre a possibilidade de o irmão ter "desaparecido sem deixar traços" (conforme as palavras do reverendo), o narrador aponta para essa divisão interna do personagem: "Sofia ficou em silêncio. Como era difícil aquela busca! Ao mesmo tempo em que ela ansiava por saber alguma coisa, o medo de chegar a uma verdade terrível a torturava" (GRAMMONT, 2015, p. 62). Em outro momento, a mesma dualidade é esboçada: "Medo. Era o que ela, Sofia, sentia. Mas medo de quê? Ela não ansiava saber o que havia acontecido ao irmão? Estremeceu, 
o passado era um som estridente no escuro. Um buraco negro" (GRAMMONT, 2015, p. 74). Não é fácil acercar-se desse passado, porque não sabe o que poderá encontrar. A metáfora "buraco negro" representa esse desconhecido que a atemoriza.

Um sentimento similar lhe ocorre ao ir para Brasília, viagem na qual tem por objetivo conversar com a filha do militar que lhe enviou o diário, com vistas a esclarecer a autoria:

O que estava fazendo ali? Tinha tanto medo quanto desejo de encontrar respostas. Sentia que estava perto, mas não sabia do quê, e a apreensão era maior do que a ansiedade. Ela intuía que, em algum momento, iria chegar a uma descoberta terrível. Uma revelação que talvez fizesse com que se arrependesse de ter começado a investigação. Julgava que o termo seria a certeza da morte do irmão e, mesmo assim, achava que valia a pena continuar. Precisava de um ponto final, uma conclusão, enfim, algo que pudesse acabar com aquela suspensão. (GRAMMONT, 2015, p. 167)

No exemplo, a dicotomia entre o temor e o desejo estão evidenciadas. Saber é imperioso para ela, contudo, ao mesmo tempo, a angustia, devido ao teor do que pode ser desvelado. Apesar desse temor, considera ser essa busca essencial para sua vida, porque, chegar ao termo, significaria tirá-la da "suspensão" em que se encontrava. Em razão disso, ela se mobiliza à travessia.

\section{0 apagamento dos rastros}

Assombrada pelo desaparecimento do irmão, na ignorância do que lhe aconteceu, Sofia acredita que sua vida está imobilizada. Nessa iminência, impõe-se a tarefa de procurar os rastros desse passado, no desejo de desvelar o que foi silenciado. Essa consiste em pesquisas e entrevistas. Leituras (o relatório e o livro Brasil: Nunca mais, a revista publicada em 1978 e as reportagens de Fernando Portela) e viagens permeiam sua investigação. Por isso, vai a São Paulo, à região do Araguaia, a Cuba e a Brasília (faz três viagens para essa cidade), onde entrevista pessoas com o objetivo de descobrir os vestígios do irmão.

No livro, nada consta sobre Leonardo, o que a frustra: "acabou desestimulada" (GRAMMONT, 2015, p. 61). Não obstante isso, decide dar continuidade à investigação com o intuito de inteirar-se sobre a menção ao seu nome "nos inúmeros processos analisados" (GRAMMONT, 2015, p. 61), marca uma entrevista com o reverendo Wright. Certamente Sofia está se referindo aos processos que constaram no relatório do projeto Brasil: Nunca mais. Entende-se a motivação da entrevista, pois o religioso foi um dos coordenadores do projeto. $\mathrm{O}$ relatório teve por base a consulta e as "cópias de 707 processos completos e dezenas de outros incompletos, num total que ultrapassou 1 milhão de páginas imediatamente microfilmadas em duas vias, para que uma pudesse ser guardada, sem riscos, fora do país" (ARQUIDIOCESE, 
2011, p. 20). Desse, resulta o livro, um resumo daquele amplo material. Ela consulta a ambos - livro e relatório - em diferentes momentos.

Nesse encontro, o reverendo lhe fala do próprio irmão, também um desaparecido. Sobre Leonardo, ao ser informado que ele lutara na guerrilha do Araguaia, o religioso adverte-a sobre a importância de saber seu codinome, porque, como os processos raramente eram instaurados, a forma de "encontrar os vestígios" era "cruzar referências a partir do testemunho dos companheiros" (GRAMMONT, 2015, p. 61). Malgrado ele não lhe dar informações sobre o irmão, ao saber que ele participou dessa luta, ele não lhe dá esperança:

- Se ele atuou na Guerrilha do Araguaia, pode ter desaparecido sem deixar traços. Dos cerca de setenta guerrilheiros que estiveram lá, a maior parte foi eliminada no local. Outros depois, apenas alguns sobreviveram - ele concluiu, com o máximo de delicadeza possível. (GRAMMONT, 2015, p. 62)

Mesmo sendo cuidadoso em sua resposta, o religioso descobre a verdade sobre os desaparecidos que não deixam rastros. Essas informações poderiam permitir-lhe, por dedução, inferir que também Leonardo teve tal fim, pois elas dão um forte indício de ele também ter sido executado. Mas Sofia não segue esse raciocínio silogístico. Essa verdade é muito cruel, e ela não tem condições de encará-la.

Seu próximo passo é a leitura da revista sobre a guerrilha do Araguaia, publicada em 1978, da qual participou, entre outros, Sergio Buarque de Holanda. Nela, alguns dados que já haviam aparecido na conversa com o reverendo estão presentes, porém descobertos com uma abordagem mais enfática. "Os organizadores escreveram uma introdução na qual comentavam o pesado silêncio em torno da Guerrilha do Araguaia" (GRAMMONT, 2015, p. 64). Quase nada é veiculado sobre esse acontecimento. Dessa leitura, Sofia surpreende-se com o número expressivo de soldados no palco da luta: "[...] de cinco a dez mil homens, para combater pouco mais de 60 guerrilheiros" (GRAMMONT, 2015, p. 65). Certamente a constatação mais impactante de suas pesquisas, talvez até discutida nessa revista (isso não fica claro), é o extermínio dos guerrilheiros, executados depois de presos e fora do cenário da luta: "Alguns dos jovens teriam sido executados muitas semanas depois de terem sido capturados. [...] Todos sumariamente eliminados" (GRAMMONT, 2015, p. 66). O extermínio dos guerrilheiros está em consonância com o relatório da Comissão Nacional da Verdade, que mostra que as Forças Armadas tinham articulado o objetivo de "aniquilação total da guerrilha na região" (BRASIL, 2014, p. 691). Na mesma perspectiva, Elio Gaspari (2014, p. 462) reflete sobre essa eliminação: “Os guerrilheiros que estavam no mato morreram todos. Morreram os que foram capturados e 
morreram os que se renderam". ${ }^{4} \mathrm{O}$ pesquisador logo esclarece que essa prática não era aleatória; pois, foi uma política de Estado, sancionada por altos escalões do governo ditatorial:

O que se sucedeu derivou de uma decisão de Estado, compartilhada pelos presidentes Emílio Garrastazu Médici e Ernesto Geisel, bem como pelos seus ministros do Exército. Isso pode ser comprovado nos elogios constantes de suas folhas de alterações, bem como na outorga da Medalha de Pacificador a mais de uma dezena deles. (GASPARI, 2014, p. 462)

Ora, este ato, além de ser hediondo, evidencia o quanto a política de extermínio estava vigorando. Ainda aqui, o seu raciocínio não a leva à conclusão de que este poderia ter sido o fim do irmão. Todavia, ela não fica imune às revelações, o que transparece ao sentir-se profundamente afetada: "A cada descoberta, sua angústia recrudescia” (GRAMMONT, 2015, p. 66). Mesmo que não relacione ao irmão, a consciência desse apagamento se impõe: "Nenhum vestígio deveria permanecer. A Guerrilha do Araguaia se tornara um movimento sem memória" (GRAMMONT, 2015, p. 66). Essas palavras estão em consonância com o que lhe dissera o reverendo. Embora essas sejam contundentes, tanto que poderiam tê-la levado à compreensão do destino do irmão, ela não faz nenhuma inferência, porém sua angústia é muito significativa.

Sua trajetória rumo a esse passado segue com a entrevista com Taco, antigo companheiro de luta do irmão. Sofia somente o conhece por esse codinome, por isso não tinha condições de procurá-lo. Uma situação fortuita lhe permite saber seu verdadeiro nome, o que lhe oportuniza marcar a primeira entrevista com ele. Nela, o candidato nada comenta sobre Leonardo, apesar de ela insistir, dizendo-lhe o quão imprescindível lhe era essa descoberta. Mesmo assim, mesmo intuindo “[...] um tumulto dentro dele” (GRAMMONT, 2015, p. 80), ele se abstém de qualquer esclarecimento. Haverá outra entrevista, na qual ele lhe falará sobre algumas ações pregressas, do tempo da militância. Na medida em que se fez a opção por seguir o mesmo percurso realizado pela personagem, as considerações sobre esse encontro serão postergadas.

Insatisfeita por não obter informações, pois nem as pesquisas bibliográficas nem as entrevistas (com o reverendo Wright e com Taco) lhe propiciam divisar qualquer rastro de

\footnotetext{
${ }^{4}$ O estudo de Roberto Vecchi (2014, p. 135-136) reitera essa questão: “O que se executou de fato, sobretudo a partir da segunda fase da repressão, a começar de 1973, foi um massacre deliberado e irrestrito: a partir desse momento, não há sobreviventes ou presos, todos os integrantes dos grupos de guerrilha são mortos, e os seus cadáveres ocultados".

5 O relatório da CNV também aponta a implicação do "comando das Forças Armadas" nessa decisão: "Como demonstram os documentos militares, a decisão de executar os guerrilheiros partiu do comando Forças Armadas e não pode, portanto, ser considerada excesso dos agentes presentes em campo em situações específicas: se eles conduziram torturas, execuções e desaparecimentos forçados foi porque essas condutas estavam previstas nos manuais de guerra que inspiraram as ações militares na região e nas decisões políticas e estratégicas adotadas pelo alto escalão do poder político no país” (BRASIL, 2014, p. 717).
} 
Leonardo, Sofia decide viajar para a região do Araguaia, o "último lugar onde ele parecia ter estado: o sul do Pará, onde ocorrera a Guerrilha do Araguaia" (GRAMMONT, 2015, p. 105). Acompanhada de um guia, visita moradores e uma aldeia indígena. Muitas das informações que eles lhe transmitem, já conhecia através das leituras que fizera antes. A despeito disso, ouvi-las de quem viveu a situação é muito mais impactante. Ela fica de tal forma afetada com, sobretudo, uma dessas histórias que aborta parte das entrevistas e a viagem e antecipa o retorno, rompendo com a programação previamente feita.

Esses relatos trazem algumas faces da repressão. São testemunhos de quem foi protagonista: de um que foi aprisionado e vítima da tortura perpetrada pelos representantes do Estado; de outros que foram cooptados pelos agentes repressores, sejam seduzidos pelo dinheiro que recebiam em pagamento das ações, sejam por se lhes acenarem com um pedaço de terra, cuja posse nunca se concretizou; sejam pelo amedrontamento. "O Exército oferecia mil cruzeiros por 'paulista capturado. Era dinheiro suficiente para a compra de um pequeno pedaço de terra. Esse tipo de incentivo, associado à intimidação, levou um camponês a denunciar um guerrilheiro com quem tinha boas relações" (GASPARI, 2014, p. 428). Observe-se o relato desses moradores.

O primeiro entrevistado foi um preso que foi torturado: "Disse que lembrava, sim, que lhe bateram muito e penduraram nele uns fios que o faziam pular como sapo. Só depois ele soube que eram choques produzidos por uma manivela, pois, na época, não havia eletricidade por ali" (GRAMMONT, 2015, p. 117-118). Nada é dito sobre o grau de envolvimento que ele tinha com os guerrilheiros, porém, o fato de eles terem curado "um filho dele que havia sido picado por uma cobra" (GRAMMONT, 2015, p. 118) já seria o bastante para que fosse preso e submetido à tortura. O relatório (BRASIL, 2014, p. 701) esclarece a arbitrariedade das prisões, o que era reconhecido pelos próprios agentes repressores, segundo os quais o contato com os guerrilheiros, movido por um gesto de solidariedade, poderia implicar no encarceramento:

[...] $90 \%$ dos que foram presos, sob a acusação de serem elementos de apoio das forças guerrilheiras, eram pessoas que - nas palavras das próprias Forças Armadas -, "dentro do hábito de hospitalidade da área, ou premidos pela presença do grupo armado", ocasionalmente forneciam algum tipo de alimento aos guerrilheiros.

$\mathrm{O}$ trecho evidencia que seguir os costumes regionais era motivo para a prisão. Uma vez detido, ato contínuo, a pessoa era submetida à tortura: "O destino era o mesmo para todo aquele que fosse acusado de manter quaisquer relações com os guerrilheiros, reitera-se, ainda que apenas ocasionais" (BRASIL, 2014, p. 702). O morador lembra dos choques, cujo mecanismo foi adaptado à precariedade local. Ou seja, a violência da tortura está posta. 
Um outro depoimento é o de um mateiro. Ele foi seduzido a colaborar com os soldados pela promessa de um lote de terra: "Os sujeitos do exército prometiam lotes a quem os guiasse até os guerrilheiros" (GRAMMONT, 2015, p. 121). No entanto, ao constatar a total inexperiência e inabilidade dos soldados ao se movimentarem na mata, transformados em alvo fácil, dissera: “- Tudo boi de piranha” (GRAMMONT, 2015, p. 122); ele foge e esconde-se em um igarapé, onde permanece por dois dias: “Tinha medo de ser pego tanto pelos 'paulistas', quanto pelos soldados, pois sabia que - depois do que aconteceu - todos deviam estar furiosos com ele" (GRAMMONT, 2015, p. 121-122). Sofia lera anteriormente sobre esse episódio nas reportagens de Fernando Portela ${ }^{6}$ por isso ainda lembra de outros detalhes relativos ao episódio, ressaltados pelo jornalista: “[...] as algemas caídas na mata, ao lado do morto, marca da inexperiência dos soldados nessas primeiras campanhas de perseguição" (GRAMMONT, 2015, p. 123). ${ }^{7}$

A visita à aldeia dos índios suruís ${ }^{8}$ dá prosseguimento às entrevistas. No relato, eles dão ênfase a um aspecto fundamental dessa guerrilha: o apagamento a que os fatos foram submetidos e o silenciamento em relação a eles. ${ }^{9}$ Os suruís temem se reportarem a esses episódios pregressos, e por um motivo muito forte: “Alguns anos depois do triste desfecho, um deles dera uma entrevista sobre o que tinha acontecido no Araguaia. Logo em seguida, foi levado por alguns homens à paisana. Ele não retornou nunca mais" (GRAMMONT, 2015, p. 124). A ruptura do silêncio teve como consequência o desaparecimento desse índio que, ao dar entrevista, violou as regras estabelecidas pelo poder repressor. ${ }^{10}$ Esse desaparecimento é responsável pelo temor que os suruís têm, por isso não desejarem falar. Entretanto, um deles rompe o silêncio e discorre sobre circunstâncias que presenciou, como a morte de guerrilheiros e a violência empregada contra os "caboclos que os ajudavam" (GRAMMONT, 2015, p. 124),

\footnotetext{
${ }^{6}$ Essas reportagens saíram no Jornal da tarde, de São Paulo, em 13 de janeiro de 1979. Elas foram publicadas no livro Guerra de guerrilhas no Brasil (PORTELA, 1979).

${ }^{7}$ De fato, essa cena está em Portela (1979, p. 25-26), no capítulo "Era fácil matar recrutas".

${ }^{8}$ Sobre os suruís, Hugo Studart (2018) refere-se ao fato de os guerrilheiros não terem feito nenhuma aliança com eles. Os militares, ao contrário, aproximaram-se desses índios, que "apenas serviram de guias, como dezenas de outros camponeses. $\mathrm{O}$ fato é que, quando eles atuaram como guias, os militares encontraram o maior número de guerrilheiros" (STUDART, 2018, p. 361).

${ }^{9} \mathrm{O}$ silenciamento sobre o evento é também constatado ao entrevistar o primeiro morador, que teme falar sobre o assunto: "Sofia perguntou como eram os guerrilheiros e do que o velho lembrava. Ele ficou quieto, porque mesmo depois de tanto tempo ainda tinha medo de tocar naquele assunto" (GRAMMONT, 2015, p. 118).

${ }^{10}$ Sobre essa imposição de silêncio na imprensa, Portela (1979, p. 27) afirma que o governo ditatorial "conseguiu manter o país ignorante dos acontecimentos (com exceção de uma grande reportagem de O Estado de S. Paulo, hoje histórica, que furou o cerco em setembro de 1972, durante a segunda campanha); [...]. Mas o segredo, imposto pelo governo, chegou a ser tão bem guardado, que nem a imprensa internacional conseguiu acesso a informações mais precisas sobre a guerrilha do Araguaia".
} 
que era tão intensa que, a muitos deles, lhes determinou o óbito. Certamente a informação mais importante é relativa ao destino dos corpos: "Depois de mortos os corpos dos guerrilheiros eram jogados em um lugar na mata, o suruí contou, imitando o som do helicóptero e, com os dedos, o movimento da hélice” (GRAMMONT, 2015, p. 125). Não para aí a violência. Esses corpos são queimados, conforme as palavras do índio:

- Depois que jogaram os defuntos lá, encheram de pneu velho e tocaram fogo - disse o rapaz. - A senhora não vai achar nada, dona. Um dia os soldados vieram, colocaram tudo em sacos e puseram dentro de um avião. Até os pedações de pneu. Eu só sei disso porque o meu pai foi contratado para ajudar. (GRAMMONT, 2015, p. 126)

Queimar os corpos e, não obstante isso, retirá-los dessa vala, levando-os para um local desconhecido, evidencia o intuito deliberado de apagamentos dos rastros. Gaspari (2014, p. 471) ressalta que nesse ato fica evidente a tentativa de destruição de qualquer vestígio:

[...] apagava o registro do extermínio. Equipes de militares mandadas ao Araguaia abriram sepulturas, retiraram os corpos espalhados pela região e levaram-nos de helicóptero para a serra das Andorinhas, onde foram queimados em fogueiras com pneus carecas.

Esses corpos permanecerão desaparecidos, de acordo com o término do capítulo: "Os corpos nunca foram devolvidos às famílias" (GRAMMONT, 2015, p. 127). "' "A ditadura fixara um padrão de conduta. Fazia prisioneiros, mas não entregava cadáveres. Jamais reconheceria que existissem. Quem morria, sumia” (GASPARI, 2014, p. 428). Nesse ato, os corpos são desaparecidos, evidenciando o apagamento a que o estado repressor submeteu esse capítulo da nossa história. É essa a perspectiva de Vecchi (2020, p. 45) ao ressaltar que a gravidade dos desaparecimentos, responsáveis pela suspensão do trabalho de luto, evidencia-se nesse ato como tentativa de aniquilamento: “[...] é mesmo uma página da história do Brasil sujeitada à eliminação e ao recalcamento induzidos" (VECCHI, 2020, p. 45). ${ }^{12}$

O último morador entrevistado é um batedor "que lhe disseram ter apanhado muitos "paulistas" (GRAMMONT, 2015, p. 129). Seu relato demonstra muita frieza e nenhum arrependimento. Sequer se refere às razões de ter entrado na luta ao lado dos militares. Sabe-se

\footnotetext{
11 "Os parentes reclamam da demora na localização de seus mortos e as Forças Armadas continuam sem prestar declarações definitivas sobre os desaparecidos na Guerrilha do Araguaia” (MORAIS; SILVA, 2005, p. 549). Observe-se que essa declaração está em livro publicado em 2005. Convém ressaltar que a situação não mudou passados mais de uma década. No livro de Studart (2018, p. 23), lê-se: “[...] as Forças Armadas, ressalve-se, até a presente data permanecem em silêncio".

12 Conforme a pesquisa realizada por Taís Morais e Eumano Silva (2005, p. 13-14), divulgada em Operação Araguaia: os arquivos secretos da guerrilha, essas diligências tiveram um êxito relativo: "Os governos militares fracassaram na tentativa de jogar a Guerrilha do Araguaia no esquecimento. Depoimentos de sobreviventes do conflito e documentação produzida pelos serviços secretos do governo preservaram por mais de três décadas a memória de um dos mais chocantes episódios da História do Brasil”.
} 
que muitos o fizeram por dinheiro ou por promessa de terra, outros cederam ao serem coagidos, temendo pela própria vida (STUDART, 2018, p. 358). Mas ele silencia sobre esse fato. Apenas confirma ter matado muitos guerrilheiros. Inclusive faz o relato de um caso: "Durante dois dias seguiu um grupo de três rapazes. Quando eles acamparam, à noite, surpreendeu-os e matou dois. Um fugiu" (GRAMMONT, 2015, p. 130). No seguimento da sua fala, ele se refere à decapitação dos mortos, por cuja ação os nativos eram recompensados. Para demonstrar como fazia com os homens, recorreu a um quati que jazia morto. ${ }^{13}$ Embora a jornalista já soubesse dessa prática dos nativos, que eram estimulados por representantes do governo; ela ficou abalada: "Sofia estremeceu" (GRAMMONT, 2015, p. 130) e logo se apoiou em Aruanã, o guia. Essas cabeças eram entregues aos soldados, sendo fotografadas: "Essas fotografias macabras serviam tanto para identificar os guerrilheiros como para aterrorizar os poucos que tinham sido pegos com vida" (GRAMMONT, 2015, p. 131). O relato é tão perturbador que se sente mal:

Felizmente o carro não estava longe. Sofia apressou-se em ir embora. Cambaleava, sua cabeça latejava. [...] Sentiu-se mal. Quando chegaram ao hotel, pagou o guia local, com pressa. Ele lhe perguntou se ela queria conhecer outro batedor, no dia seguinte. Ela disse que não. Não podia mais. Tinha planejado ficar mais um par de dias, mas decidiu ir embora assim que se recuperasse. (GRAMMONT, 2015, p. 131)

A reação de Sofia mostra o quão impactantes são as palavras do batedor. Se antes o índio suruí lhe falara da ocultação dos cadáveres, esse mateiro lhe apresenta o movimento oposto: a exibição dos corpos. A decapitação e o ato de fotografá-los revelam-se um espetáculo macabro a que a personagem não fica imune, o que seu corpo deixa transparecer. Convém lembrar a arguta reflexão de Vecchi (2014, p. 136): “Araguaia, na verdade, acaba por se tornar a brecha que deixa entrever o rosto do horror do regime, em que a produção tanatopolítica que se articulou pela morte, a destruição e o ocultamento do corpo do inimigo é fruto de uma deliberada racionalidade".

Cuba é o próximo itinerário de Sofia. Apesar de suas pesquisas indicarem que "[...] a maioria dos jovens que foram para o Araguaia" (GRAMMONT, 2015, p. 152) haviam ido para a China, ela se decide pela viagem, seguindo a informação de Taco, que afirmara que ambos fizeram treinamento em Cuba. Por isso, parte na expectativa de "descobrir mais" (GRAMMONT, 2015, p. 152). Conquanto se encontre com o treinador de guerrilheiros, nenhum vestígio da passagem do irmão pela ilha é divisado. Guilhermo, a quem entrevista, não

\footnotetext{
13 "Em consonância, os relatos de camponeses detidos nas bases militares e de outros moradores da região dão conta de que, entre os procedimentos adotados pelos agentes do Estado no tratamento dos corpos dos militantes executados sumariamente, consta o corte de cabeça e mãos e o abandono dos corpos nas matas, além do transporte em helicópteros de detidos mortos ou prestes a serem executados, como relatou o ex-cabo do Exército Manuel Messias Guido" (BRASIL, 2014, p. 712).
} 
lhe dá a tão ansiada resposta: “- [...] Não me lembro de seu irmão, mas ele podia ser cada um dos jovens cheios de esperanças que nos procuravam" (GRAMMONT, 2015, p. 152). Nada específico sobre Leonardo. Talvez o óbice para essa identificação seja seu desconhecimento do codinome do irmão. Não flagrar nenhum vestígio é frustrante. Entretanto, já "não podia parar" (GRAMMONT, 2015, p. 153).

A próxima etapa é Brasília. Sofia faz três viagens para essa cidade. Na primeira conversa, Laura, a filha do militar que "lutou contra guerrilheiros no Pará" (GRAMMONT, 2015, p. 171), a coloca a par do derrame do pai e afirma que, depois desse, ela enviou o relato para o endereço indicado por ele. Essa informação é de extrema relevância, afinal, quem tinha a posse do relato era um militar que lutara contra a guerrilha. Ela, porém, não lhe dá o devido valor. Este seria um rastro de Leonardo. A posse do manuscrito pelo militar, somado às histórias que ouviu durante sua estada no Araguaia, poderiam ter-lhe permitido intuir o mesmo fim trágico para o irmão. Contudo, ela não persegue esse indício. Talvez ainda não estivesse preparada para esse enfrentamento com a verdade. Mesmo que Sofia não tenha explorado esse fato, ele não é de menor importância.

Na segunda ida à cidade, outros aspectos são aclarados. Essa viagem é decorrente de um telefonema de Laura, que deseja lhe entregar o caderno de anotações do pai. Nessa conversa a filha do militar conta-lhe que os originais eram manuscritos. Todavia, ela é contundente ao dizer que esses não são de autoria do pai: “- [...] Com certeza não foi escrito por meu pai. Além do mais, não era a letra dele" (GRAMMONT, 2015, p. 177). Na continuidade da conversa, Laura lhe explica que foi ela que o enviou para o endereço previamente "escrito no envelope" (GRAMMONT, 2015, p. 178) pelo próprio pai. Ou seja, antes do AVC ele pretendia enviá-lo. Nesse momento, Sofia tem uma intuição, a qual não é desvendada para o leitor. Por isso, pergunta-lhe pelo comprovante. Ao tê-lo em mãos, "Ela levou um susto ao ver o nome do destinatário. Cerrou os olhos para conter o estremecimento que a tomou inteira" (GRAMMONT, 2015, p. 179). O impacto ao ler o nome lhe provoca uma reação física, a qual é percebida por Laura. Em capítulo posterior, o segredo do amigo oculto de Marcos é esclarecido: é Luisa a amiga que não deseja ser identificada.

De volta à cidade, a conversa com a mãe é o outro passo de seu percurso. Ela é muito esclarecedora, pois lhe dá uma informação fundamental: o irmão é o autor da segunda parte do relato: “- Era... era a letra do seu irmão!” (GRAMMONT, 2015, p. 188). Se na conversa com Marcos a questão da autoria era apenas uma hipótese plausível, mas sem nenhuma confirmação: 
“- [...] Mas como posso ter certeza?” (GRAMMONT, 2015, p. 187) - com esclarecimentos da mãe essa dúvida foi sanada.

Apesar dessa confirmação, há perguntas sem respostas. Um ano depois de iniciadas as pesquisas, Sofia se dá conta de que "não conseguira descobrir nada de concreto sobre o paradeiro de Leonardo" (GRAMMONT, 2015, p. 195). Ao refazer suas anotações, surpreendese com uma frase sobre Taco, escrita por ocasião do primeiro encontro. Essa aponta para a sua percepção de que ele não teria falado tudo: "Acho que ele não disse tudo o que sabe" (GRAMMONT, 2015, p. 195). Questiona-se sobre as próprias razões de escrever tal observação. Considerando-se nesse momento mais preparada para "Extrair mais informações desse sujeito" (GRAMMONT, 2015, p. 195), marca outra entrevista. Taco somente acede depois de sua insistência, pois ele "Não parecia querer vê-la de novo" (GRAMMONT, 2015, p. 195). Sua primeira pergunta foi sobre o codinome do irmão. Ao ouvir dele que era Antônio, ela pensa que esse "Era mais um indício da autenticidade do relato que sua mãe recebera, pois a guerrilheira usava a inicial A. para se referir ao companheiro" (GRAMMONT, 2015, p. 196).

Taco faz várias revelações: algumas específicas a Leonardo (fato de ter ido treinar guerrilha em Cuba), outras sobre as ações de resistência (assaltos) e o movimento repressivo que elas desencadeavam. Essa está manifesta na atuação do Esquadrão da Morte, que os “caçava como bichos" (GRAMMONT, 2015, p. 197). Desse relato, o que mais a perturba é o justiçamento de um companheiro que desejava deixar a organização. O desaparecimento do jovem por alguns dias torna-os "paranoicos" (GRAMMONT, 2015, p. 198); e o seu retorno sem explicações plausíveis para o sumiço, eleva a preocupação ao grau máximo. Assustados, eles temem que ele tenha "sido cooptado pelos agentes de repressão" (GRAMMONT, 2015, p. 198). É nessa conjuntura que ele é condenado pelo Tribunal Revolucionário. Leonardo participou da sua punição, sendo um dos que o mataram. Essa ação o afeta sobremaneira, conforme as palavras do candidato:

- Aí é que está: Leonardo ficou muito impressionado com a execução. Não conseguia
mais dormir direito. Nos poucos dias em que ficamos juntos no aparelho, acordava
toda a hora e me dizia que ficava vendo o rapaz no chão, olhos arregalados do susto
da morte, esvaído em sangue. Foram vários tiros, com revólveres de calibres
diferentes, então, pode imaginar o resultado... Seu irmão ficou muito perturbado.
Olha, sinto ter de dizer isso, mas Leonardo ficou tão estranho depois desse episódio
que quase comecei a desconfiar dele também. Ele delirava, contava episódios da
infância... (GRAMMONT, 2015, p. 200-201)

Atormentado, ele decide ir para o sul do Pará, na região do Araguaia. É a mãe quem se reporta ao estado emocional do filho, em sua última conversa com ele, antes da sua partida. Isso ela the revela em outro momento. 
Depois dessa descoberta, em que a imagem do irmão é posta em xeque, Sofia dá continuidade a sua trajetória "retorna[ndo] aos escritórios do Brasil: Nunca Mais para checar a veracidade e os detalhes daquela história” (GRAMMONT, 2015, p. 202). Nesse momento, sabedora do codinome do irmão, ela pode conferir sua participação nesse episódio lamentável, confirmando essa execução e que o "guerrilheiro Antônio [...] também teria participado do ato truculento" (GRAMMONT, 2015, p. 202). A imagem de Leonardo que ela preservava na memória era outra, por isso “[...] um misto de decepção e revolta" (GRAMMONT, 2015, p. 203) se impõe.

Uma dúvida permanece: a de o irmão ter ido ou não para o Araguaia. "A resposta a essa pergunta era fundamental, pois, dependendo do resultado, ele poderia estar vivo ou morto" (GRAMMONT, 2015, p. 204). Certamente, a entrevista com o revendo Wright, os depoimentos dos moradores do Araguaia e do índio suruí, bem como suas pesquisas são responsáveis por tal inferência. Em nova conversa com a mãe, essa dúvida é elucidada: ela relata que ele foi para o Araguaia. A progenitora expõe o último encontro com o filho. Antes de ele viajar para o Pará, foi visitá-lo em São Paulo, quando ele lhe contou sobre Mariana, a jovem por quem estava apaixonado e com quem partiria. Luisa vai além, contando-lhe que a moça conseguiu sair da região e deu à luz a uma filha. Ambas concordam que a primeira parte do relato seja de sua autoria. As expectativas de Sofia de encontrar a cunhada e a sobrinha logo são frustradas, pois, segundo a mãe, “- [...] ela tinha desaparecido junto com a filha” (GRAMMONT, 2015, p. 217) - notícia trazida pelo pai, que à época, foi até a cidade onde elas moravam.

Abre-se, então, um novo caminho de busca para Sofia: procurar notícias de Mariana. Diante do novo dado, ela consulta novamente os relatórios de Brasil: Nunca Mais: "Segundo os relatos, a moça tinha conseguido deixar o Araguaia e fora para São Paulo, mas depois desapareceu misteriosamente" (GRAMMONT, 2015, p. 220). Então, vai à cidade onde a jovem morava com vistas a falar com seus progenitores. Nesse sentido, refaz o caminho do seu pai, mas, como ele, não tem êxito em sua empreitada. De acordo com eles, “- Um dia, ela simplesmente desapareceu" (GRAMMONT, 2015, p. 222).

A confirmação de que a segunda parte do diário era do irmão, e a suspeita de que a primeira tivesse sido escrita pela cunhada, não encerram suas investigações. Sofia deseja saber mais. É com esse intuito que vai novamente a Brasília, pois "esperava que Laura a fizesse, talvez, chegar a outros militares que teriam estado no Araguaia com o pai dela" (GRAMMONT, 2015, p. 224). Ao ser informada de que o irmão fora guerrilheiro no Araguaia, Laura sugere que "O relato podia ter sido encontrado quando Leonardo foi capturado [...]" (GRAMMONT, 
2015, p. 224). No entanto, essa possibilidade, cujo enfrentamento é extremamente doloroso, não é encarada por ela, o que o narrador explicita.

Quando se prepara para ir embora, o acaso a faz conhecer Cíntia, supostamente a irmã de Laura. Devido ao seu conhecimento prévio sobre a sobrinha desaparecida, sobre a participação do militar na guerrilha, ao ver a jovem, Sofia a examina com um olhar aguçado, logo percebendo entre Cíntia e Laura diferenças muito contrastantes: "Era visivelmente adotada ou, no mínimo, meia-irmã” (GRAMMONT, 2015, p. 225). O sequestro de crianças, filhos de militantes, adotadas por militares era uma prática durante os anos de chumbo. ${ }^{14} \mathrm{O}$ encontro com Cíntia/Luisa em Paris é a última etapa do seu percurso. É essa a última cena do romance, que se apresenta como o início de uma conversa, uma conversa que pretende desvelar o passado da jovem, restituindo-lhe a identidade que fora usurpada com o sequestro e a adoção. Encerramento de um ciclo e início de outro?

\section{Conclusão}

As diversas narrativas que se cruzam no romance permitem contemplar várias faces da guerrilha do Araguaia. Ao realizar sua travessia - visitando lugares, falando com pessoas e realizando pesquisas -, Sofia se depara com diferentes perspectivas sobre esse evento histórico. Evento que o governo ditatorial procurou apagar, executando os guerrilheiros e sumindo com os corpos. Não obstante o desaparecimento do irmão a ter mobilizado a sua busca, não descobre nada de definitivo sobre o seu paradeiro ou sobre o seu destino. Nas páginas finais do romance, a dúvida permanece:

Todas aquelas conjeturas podiam não passar de fantasias, depois de uma vida inteira presa à angústia daquela falta. A dor fora aguçada a um limite máximo naqueles meses de busca. Tantas perguntas ficariam eternamente sem resposta! Sofia jamais teria certeza de nada. (GRAMMONT, 2015, p. 228)

Esse pensamento surge ao término do seu percurso - o próximo passo é Paris, onde Sofia vai ao encontro da sobrinha com vistas a contar-lhe a verdade sobre sua ascendência. Sobre Leonardo, seu destino continua ignorado. Porém, nesses trânsitos, ela faz algumas constatações: tem conhecimento da execução dos guerrilheiros; confirma a autoria de parte do diário; e de esse estar em posse de um militar que participou da luta. Ora, esses elementos se

\footnotetext{
${ }^{14}$ Conquanto seja um tema interessante, o qual está presente no romance, ele extrapola o âmbito dessa discussão. Para mais informações sobre sequestros e adoções de crianças filhas(os) de militantes pelos militares, ver Cativeiro sem fim: as histórias dos bebês, crianças e adolescentes sequestrados pela ditadura militar no Brasil (2019), de Eduardo Reina.
} 
afiguram suficientes para a conclusão de que o irmão também teria tido o mesmo fim trágico dos outros guerrilheiros. Mesmo que ela não faça essa inferência, há que atentar para as manifestações de dor física que a acometem em algumas circunstâncias. O corpo parece estar sinalizando para uma verdade que conscientemente se nega a encarar.

Ainda que não haja nada de mais explícito, ainda que ela não realize uma perquirição nesse sentido, que poderia levá-la a conclusões dolorosas, ainda assim se acredita que essa viagem possivelmente contribuiu para a realização do luto. É interessante considerar que a mãe, ao sonegar-lhe informações, é responsável por seu percurso. Surpreende que tudo o que Sofia descobriu nas suas andanças já eram do conhecimento da progenitora e, inclusive, foi quem lhe elucidou algumas dúvidas: o fato de o irmão ter ido para a região do Araguaia; e a confirmação de que ele era o autor da segunda parte do diário. Esses dados foram cruciais, pois lhe permitiram esclarecer a participação do irmão na guerrilha, o que poderia levá-la à conclusão de ele estar morto, ter sido executado como os outros. A progenitora somente lhe faz essas revelações - e muitas outras também ${ }^{15}$ - depois do término da sua trajetória, quando a filha já fizera sua própria caminhada.

Ao perguntar à progenitora sobre as razões de seu silêncio antes, essa lhe responde: "Não, Sofia. Sem descobrir por si mesma, talvez você não acreditasse em mim" (GRAMMONT, 2015, p. 189). Na ignorância dos fatos e ansiosa por notícias sobre o irmão, Sofia realiza sua própria caminhada. Ao fazê-lo, refaz alguns dos passos do pai. No entanto, suas descobertas se restringem quase que exclusivamente ao que Luisa já sabia. Mesmo assim, fazer essa viagem foi fundamental, pois, dessa forma, assumiu para si a responsabilidade de saber o que acontecera ao irmão, encarando os fatos, a realidade cruel de que jovens haviam sido executados, e de que seus corpos foram levados para lugares ignotos. Esse percurso, em que sua dor foi revivida, intensificando-se ao grau máximo, parece ter contribuído para a elaboração desse trauma. E o reconhecimento da sobrinha como filha de Leonardo - "as covinhas no rosto de Cíntia quando ela sorria, seus olhos cor de mel encimados por longos cílios, ela era inteira... Leonardo" (GRAMMONT, 2015, p. 227) - aponta para isso. A decisão de ir ao seu encontro em Paris para revelar-lhe a verdade pode significar a abertura de uma nova etapa. Essa outra viagem permite inferir que uma compreensão do passado (elaboração do trauma?) pode afigurar

\footnotetext{
15 A mãe lhe relata as viagens do marido com vistas a saber notícias do filho: foi ao Araguaia junto com outros familiares de desaparecidos; à Brasília, quando do recebimento dos diários; à cidade onde morava Mariana, porém, nessa ocasião, ela já estava desaparecida. A progenitora, inclusive, sabe do justiçamento de um companheiro, do qual o filho participou.
} 
uma ressignificação do presente - lembre-se de que a mãe não desejou sequer conhecer a neta, preferindo continuar esperando o retorno do filho. Realizar esse percurso foi um movimento necessário para que Sofia pudesse inaugurar esse novo ciclo.

\section{Referências}

ARNS, Dom Paulo Evaristo. Prefácio. In: ARQUIDIOCESE DE SÃO PAULO. Brasil: Nunca mais. Prefácio de Dom Paulo Evaristo Arns. Petrópolis: Vozes, 2011.

ARQUIDIOCESE DE SÃO PAULO. Brasil: Nunca mais. Petrópolis: Vozes, 2011.

ASSMANN, Aleida. Espaços da recordação: formas e transformações da memória cultural. Trad. Paulo Soethe. Campinas, SP: Editora da Unicamp, 2011.

BRASIL. Comissão Nacional da Verdade: Relatório. Brasília, DF: CNV, v. 1, 2014. Disponível em: http://cnv.memoriasreveladas.gov.br. Acesso em: 07 de julho de 2021.

FIGUEIREDO, Eurídice. A literatura como arquivo da ditadura brasileira. Rio de Janeiro: 7Letras, 2017.

FINAZZI-AGRÒ, Ettore. (Des)memória e catástrofe: considerações sobre a literatura pósgolpe de 1964. Estudos de Literatura Brasileira Contemporânea, Brasília, n. 43, p. 179-189, jan./jun. 2014. Disponível em: //www.redalyc.org/articulo.oa?id=3231300619008. Acesso em: 13 de julho de 2021.

GAGNEBIN, Jeanne Marie. O preço de uma reconciliação extorquida. In: TELES, Edson; SAFATLE, Vladimir (orgs.). O que resta da ditadura: a exceção brasileira. São Paulo: Boitempo, 2010. p. 177-186.

GAGNEBIN, Jeanne Marie. Lembrar escrever esquecer. São Paulo: Ed. 34, 2006.

GASPARI, Elio. A floresta dos homens sem alma. In: A ditadura escancarada. Rio de Janeiro: Intrínseca, 2014. p. 407-473.

GINZBURG, Jaime. Memória e ritual em "O velório", de Bernardo Kucinski. In: OLIVEIRA, Rejane Pivetta; THOMAZ, Paulo C. Literatura e ditadura. Porto Alegre: Zouk, 2020. p. 115128.

GRAMMONT, Guiomar. Palavras cruzadas. Rio de Janeiro: Rocco, 2015.

MORAIS, Taís; SILVA, Eumano. Operação Araguaia: os arquivos secretos da guerrilha. São Paulo: Geração Editorial, 2005.

PORTELA, Fernando. Guerra de guerrilhas no Brasil. Informações novas. Documentos inéditos e na íntegra. São Paulo: Global, 1979. 
REINA, Eduardo. Cativeiro sem fim: as histórias dos bebês, crianças e adolescentes sequestrados pela ditadura militar no Brasil. São Paulo: Alameda, 2019.

SAFATLE, Vladimir. Do uso da violência contra o estado ilegal. In: TELES, Edson; SAFATLE, Vladimir (orgs.). $O$ que resta da ditadura: a exceção brasileira. São Paulo: Boitempo, 2010. p. 237-252.

SELIGMAN-SILVA, Márcio. Apresentação da questão: a literatura como trauma. In:

SELIGMAN-SILVA, Márcio (org.). História, Memória, literatura: o testemunho na era das catástrofes. São Paulo: Ed. da UNICAMP, 2003. p. 45-58.

STAUDT, Sheila Katiane. Memórias de uma "guerra suja" em Palavras cruzadas, de Guiomar de Grammont. In: GOMES, Gínia Maria. Narrativas brasileiras contemporâneas: memórias da repressão. Porto Alegre: Polifonia, 2020. p. 85-110.

STUDART, Hugo. Borboletas e lobisomens: vidas, sonhos e mortes dos guerrilheiros do Araguaia. Rio de Janeiro: Francisco Alves, 2018.

TELES, Janaína de Almeida. Os familiares de mortos e desaparecidos políticos e a luta por "Verdade e justiça" no Brasil. In: TELES, Edson; SAFATLE, Vladimir (orgs.). O que resta da ditadura: a exceção brasileira. São Paulo: Boitempo, 2010. p. 253-298.

VECCHI, Roberto. O passado subtraído da desaparição forçada: Araguaia como palimpsesto. Estudos de literatura brasileira contemporânea, n. 43, p. 133-149, jan./jun. 2014. Disponível em: //www.redalyc.org/articulo.oa?id=3231300619008. Acesso em: 13 de julho de 2021.

VECCHI, Roberto. A impossível memória do Araguaia: um patrimônio sem memorial? In: OLIVEIRA, Rejane Pivetta de; THOMAZ, Paulo C. Literatura e ditadura. Porto Alegre: Zouk, 2020. p. 45-58. 